\title{
PARTISIPASI MASYARAKAT DALAM PEMBANGUNAN BERKELANJUTAN BIDANG KEBUDAYAAN
}

\section{(Studi Fenomenologi: Konversi Belis Gading Gajah Dalam Upacara Adat Perkawinan Masyarakat Lamaholot Di Kabupaten Flores Timur, Provinsi Nusa Tenggara Timur)}

\author{
Oleh: Ludovikus Bomans Wadu*
}

\begin{abstract}
This research is done based on the phenomenon among the citizen of Lamaholot in converting the elephant's trunk (Gading Gajah-GG) as Belis into the other form. Phenomenological study was applied in this research with qualitative approach which focused on portraying the participation of the citizen in the sustainable development. Main problems in this research were formulated into some research questions, such as 1) How do the perceptions of the citizen of Lamaholot on the conversion of $G G$ as Belis into the other form? 2) How are the participation of the citizen of Lamaholot in the sustainable development? Data were collected through observation, interview and document analysis. The results show that 1) the perceptions of the citizen of Lamaholot on the conversion of GG as Belis is to preserve culture, 2) the form of citizen participation is reducing the number of prosecutions of the use of $G G$ as well as converting it into the other form. This citizen action taken to support the concept of sustainable development because they are wise in making decisions.
\end{abstract}

Keywords: Elephant trunk, sustainable development

\section{PENDAHULUAN}

Kebudayaan di Indonesia banyak menggunakan simbol berupa benda-benda yang mewakili suatu gagasan tertentu dalam setiap upacara adat. Walaupun simbol bukanlah nilai itu sendiri, tetapi simbol sangatlah dibutuhkan untuk kepentingan penghayatan akan nilai-nilai yang diwakilinya. Benda-benda tersebut mengandung nilai dan norma yang sangat berguna dalam mengatur tata kehidupan manusia. Namun seiring perjalanan waktu dan keterbatasan sumber daya alam mengakibatkan benda-benda tersebut sulit untuk didapatkan. Salah satu budaya yang turut terkena imbas dari kelangkaan tersebut adalah budaya perkawinan pada

\footnotetext{
*Mahasiswa Departemen Pendidikan Kewarganegaraan Sekolah Pascasarjana Universitas Pendidikan Indonesia. E-mail: ludovikus_bomans@yahoo.com
} 
masyarakat Lamaholot di Kabupaten Flores Timur-Nusa Tenggara Timur (NTT).

Masyarakat

Lamaholot

menggunakan Gading Gajah yang kemudian disingkat GG sebagai Belis atau seserahan yang diberikan kepada keluarga perempuan pada saat upacara adat perkawinan. Bagi masyarakat Lamaholot GG merupakan salah satu benda yang digunakan dalam upacara perkawinan karena bagi masyarakat Lamaholot memiliki nilai-nilai tertentu. Dalam perjalanan waktu seiring perkembangan zaman, GG sulit ditemukan karena gajah telah menjadi salah satu kategori hewan langkah yang tidak boleh diburu untuk diambil gadingnya.

Kondisi seperti yang dikemukakan diatas mengakibatkan pemenuhan tuntutan adat perkawinan sulit dilaksanakan. Agar nilai-nilai budaya yang ada pada masyarakat Lamaholot tetap berkelanjutan, maka dibutuhkan sebuah tindakan penyesuaian yang mengakomodir konsep pelestarian budaya yang sesuai dengan kondisi kekinian. Dengan demikian kiranya penting untuk menggantikan GG dengan benda lain dalam adat perkawinan masyarakat Lamaholot. Hal ini sematamata untuk menjamin dan menjaga keberlanjutan adat perkawinan pada budaya masyarakat Lamaholot.

Dalam rangka menjaga kebudayaan agar tidak hilang ditelan zaman, pemerintah telah mengeluarkan Aturan Bersama Menteri Dalam Negeri Dan Menteri Kebudayaan Dan Pariwisata tentang kewajiban mempertahankan kebudayaan. Aturan tersebut tertuang dalam Nomor : 42 tahun 2009 dan Nomor 40 Tahun 2009, tentang Pedoman Pelestarian Kebudayaan. Dalam Pasal 19 yang berbunyi :

(1) Masyarakat berperan serta dalam pelestarian kebudayaan.

(2) Peran serta masyarakat sebagaimana dimaksud pada ayat (1) dapat dilakukan melalui perorangan, organisasi kemasyarakatan bidang kebudayaan (lembaga adat, masyarakat adat, Desa, kelompok, perkumpulan, perhimpunan, atau yayasan), dan/atau forum komunikasi kebudayaan di provinsi, kabupaten/kota, dan Desa.

(3) Peran serta masyarakat serta sebagaimana dimaksud pada ayat (1) meliputi: 
a. Berperan aktif dalam menanamkan pemahaman kebhinnekaan, memperkokoh jati diri bangsa, menumbuhkan kebanggaan nasional, dan mempererat persatuan bangsa;

b. Berperan aktif dalam mengembangkan

kebudayaan melalui dialog, temu budaya, sarasehan, dan lain sebagainya; dan

c. Memberikan masukan dan membantu kepala daerah dalam pelestarian kebudayaan.

Dengan demikian maka setiap warga negara berkewajiban untuk berpartisipasi dalam melestarikan budaya serta menghormati dan menghargai keberagaman yang ada di Indonesia.

Konsep pembangunan berkelanjutan merupakan terobasan untuk meningkatkan taraf hidup manusia dengan menyesuaikan keterbatasan sumber daya alam dan kebutuhan manusia. Penyesuaian yang dilakukan manusia dalam rangka memenuhi kebutuhannya turut mempengaruhi sebuah kebudayaan dan bahkan melahirkan budaya baru. Hal ini menempatkan kebudayaan sebagai hal yang dinamis. Ki Hajar Dewantara ( Sulasman dan Gumilar, 2013, hlm. 151) bahwa "budaya itu mengalami perubahan, yaitu ada waktunya lahir, tumbuh, maju, berkembang, berubah, menjadi tua dan mati, seperti hidup manusia." Hal ini terkait dengan teori evolusi kebudayaan, bahwa suatu budaya akan mengalami perubahan sesuai dengan jamannya.

Bidang sosial-budaya merupakan salah satu perspektif yang diusung oleh pembangunan berkelanjutan. Karena bidang sosial-budaya merupakan aspek penting yang berkaitan dengan kehidupan banyak orang. Selain perspektif sosialbudaya, pembangunan berkelanjutan juga mengusung aspek lainnya yakni aspek lingkungan dan aspek ekonomi sebagai suatu kesatuan yang utuh dan menyeluruh. Ketiga perspektif dimaksud diusung sebagai respon terhadap kondisi kekinian masyarakat yang secara urgen hadir dalam suatu mata rantai pembangunan. Urgensitas ketiga komponen ini secara signifikan terlihat dalam komunitas dan kompetensi masyarakat global.

Kesesuaian sumber daya alam yang tidak sesuai dengan kebutuhan manusia menjadi masalah utama dalam era 
keberlanjutan ini. Konsep tentang pembangunan berkelanjutan muncul sejak tahun 1890-an. Pada saat itu PBB melalui UNESCO mencanangkannya sebagai tindakan nyata dalam memajukan perekonomian dan perkembangan sosial serta pelestarian terhadap lingkungan hidup (Kemendiknas 2010). Pembangunan berkelanjutan yang dimaksudkan oleh UNESCO mengacu pada peningkatan taraf hidup masyarakat dan pelaksanaan pembangunan yang efisien dengan mempertimbangkan keberadaan lingkungan sebagai tempat yang kondusif yang menjamin keberlangsungan hidup umat manusia.

Implementasi pembangunan berekelanjutan mempertimbangkan ketiga perspektif seperti yang dikemukakan oleh UNESCO diatas. Untuk itu dibutuhkan instrumen khusus yang berfungsi untuk meningkatkan partisipasi masyarakat sehingga kerangka pembangunan berkelanjutan dapat berjalan sesuai dengan tujuannya. Instrumen khusus tersebut muncul dari penjabaran Education of sustainable for development (ESD) yang secara khusus bertujuan untuk menDesain melaksanakan serta mengevaluasi hal-hal yang berkaitan dengan pembangunan baik yang telah dilaksanakan maupun yang akan dilaksanakan. Dengan demikian aspek pendidikan dijadikan sebagai ujung tombak utama dalam merealisasikan dan menjamin terciptanya partisipasi publik.

Dalam konteks keindonesiaan kita kiranya konsep ESD harus ditopang dengan pemahaman dari warga negara dalam mewujudkan partisipasi dimaksud. Oleh karena itu proses penyadaran untuk mengubah perilaku dan gaya hidup yang cenderung konsumtif dan destruktif perlu ditanamkan dan dikembangkan mulai dari pendidikan formal. Ruang yang kiranya tepat dalam membentuk karakter warga negara melalui jalur pendidikan terakomodir melalui pendidikan kewarganegaraan (PKn). Namun lebih lanjut, pemahaman terhadap pendidikan kewarganegaraan harus juga mengarah pada lahirnya pola pendidikan lokal yang secara teknis tidak dapat direalisasikan dalam pendidikan formal. Hal ini mengingat PKn tidak hanya dapat dipelajari di persekolahan tetapi juga dimasyarakat. Cogan (dalam Budimansyah dan Suryadi, 2008:5):

Citizenship education or education for citizenship...The more inclusive term and encompasses both these in-school experiences as well as out-of-school or nonformal/informal learning which 
takes place in the family, the religious organization, community organizations, the media etc, which help to shape the totality of the citizen.

Pernyataan diatas menunjukan bahwa pendidikan kewarganegaraan mencakup pengalaman belajar disekolah dan diluar sekolah, seperti yang terjadi di lingkungan keluarga, dalam organisasi keagamaan, dalam organisasi kemasyarakatan. Penjelasan diatas sesuai dengan salah satu tujuan dari Pendidikan Kewarganegaraan (PKn). Wahab dan Saprya, (2011, hlm. 311) mengemukakan tujuan PKn adalah "Untuk membentuk warga negara yang baik (to be good citizens)." Warga negara yang baik tentunya mampu berpikir dan bertindak sesuai dengan tuntutan dan harapan negara. Azis Wahab (dalam Wahab dan Saprya, 2011, hlm. 311) mengidentifikasi warga negara yang baik adalah "warga negara yang memahami dan mampu melaksanakan dengan baik hak-hak dan kewajibannya sebagai individu warga negara, memiliki kepekaan dan tanggung jawab sosial ...". Dengan berpartisipasi melestarikan budaya bangsa maka individu telah menjalankan tujuan dari PKn karena mampu menjalankan kewajibannya sebagai warga negara yang diharapkan oleh negara.
Upaya untuk mengubah perilaku dan gaya hidup bagi transformasi masyarakat yang positif ini berkaitan dengan pembentukan karakter warga negara. Cogan dalam Sapriya (2004) mengemukakan bahwa ada delapan karakteristik yang perlu dimiliki warga negara sehubungan dengan semakin beratnya tantangan yang harus dihadapi dimasa mendatang. Karakteristik warga negara tersebut meliputi, pertama; kemampuan mengenal dan mendekati masalah sebagai warga negara masyarakat global. Kedua; kemampuan bekerjasama dengan orang lain dan memikul tanggung jawab atas peran atau kewajibannya dalam masyarakat. Ketiga; kemampuan untuk memahami, menerima, dan menghormati perbedaan-perbedaan budaya. Keempat; kemampuan berpikir kritis dan sistematis. Kelima; kemauan menyelesaikan konflik dengan cara damai tanpa kekerasan. Keenam; kemauan mengubah gaya hidup dan pola makanan pokok yang sudah biasa, guna melindungi lingkungan hidup. Ketujuh; memiliki kepekaan terhadap dan mempertahankan hak azasi manusia (seperti hak kaum wanita, minoritas etnis, dsb). Kedelapan; kemauan dan kemampuan berpartisipasi dalam kehidupan politik pada tingkatan pemerintahan lokal, nasional, dan 
internasional. Dengan demikian pendidikan untuk pembangunan berkelanjutan sangat berkaitan erat dengan PKn.

Berkaitan dengan partisipasi dan karakter warga negara dalam kerangka budaya maka penelitian ini berkenan untuk menelaah kondisi yang sedang terjadi pada masyarakat Lamaholot. Secara khusus akan menelusuri hal-hal yang berkaitan dengan pemanfaatan GG serta pengkonversiannya dalam menjamin keberlangsungan upacara adat perkawinan. Kiranya kondisi riil kehidupan budaya akan dijadikan obyek dalam penelitian ini. Hal ini senada dengan yang dikemukakan oleh Somantri (dalam Wahab dan Saprya, 2011, hlm. 316); bahwa “Objek studi Civics dan Civics Education adalah warga negara dalam hubungannya dengan organisasi kemasyarakatan, sosial, ekonomi, agama, kebudayaan dan negara." Dengan demikian kebudayaan sangat erat kaitannya dengan PKn karena merupakan salah satu objek kajian dari PKn. Penelitian ini dilakukan tidak sekedar menelusuri fenomena yang terjadi namun lebih dari itu diniati untuk memberikan konstruk pemikiran baru yang merujuk pada terciptanya implementasi pembangunan berkelanjutan.

\section{Rumusan Masalah}

Berdasarkan latar belakang masalah penelitian di atas, maka peneliti mengajukan pertanyaan penelitian sebagai berikut:

1. Bagaimana persepsi masyarakat Lamaholot terhadap konversi Belis GG ke bentuk lain?

2. Bagaimana partisipasi masyarakat Lamaholot dalam pembangunan berkelanjutan?

\section{Tujuan Penelitian}

Tujuan umum pemenelitian ini untuk mendeskripsikan fenomena yang berkembang di masyarakat tentang; Konversi Belis GG dalam upacara adat perkawinan pada masyarakat Lamaholot di Kabupaten Flores Timur - Nusa Tenggara Timur, dengan mendeskripsikan bagaimana partisipasi warga negara dalam mendukung pembangunan berkelanjutan.

1. Mendeskripsikan bagaimana persepsi masyarakat Lamaholot terhadap konversi Belis GG ke bentuk lain.

2. Mendeskripsikan bagaimana partisipasi masyarakat Lamaholot dalam pembangunan berkelanjutan. 


\section{METODE PENELITIAN}

Desain penelitian ini menggunakan pendekatan kualitatif dengan metode fenomenologi. Menurut Bogdan dan Taylor dalam Moleong, (2007, hlm.4) "penelitian kualitatif sebagai prosedur penelitian yang menghasilkan data deskriptif berupa katakata tertulis atau lisan dari orang-orang dan perilaku yang dapat diamati." Pendekatan penelitian kualitatif merupakan sebuah metode penelitian yang berlandaskan pada filsafat postpositivisme. Metode fenomenologi berfokus pada pengalaman subyektif manusia dan interpretasi dunia. Fenomenologi juga menekankan aspek subjektif dari perilaku manusia. Oleh karena itu peneliti berusaha untuk masuk ke dalam dunia konseptual para pemangku adat, tokoh masyarakat dan masyarakat Lamaholot sehingga peneliti mengerti apa dan bagaimana peran dan partisipasi masyarakat dalam membangun kebudayaan yang berkelanjutan.

Sebagaimana dijelaskan Schutz dalam Sudikin (2002) bahwa tugas fenomenologi adalah menghubungkan antara pengetahuan ilmiah dengan pengalaman sehari-hari dari kegiatan dimana pengalaman dan pengetahuan berakar. Tradisi fenomenologi berkonsentrasi pada pengalaman pribadi termasuk bagian dari individu-individu yang ada saling memberikan pengalaman satu sama lainnya. Inti dari tradisi fenomenologi adalah mengamati kehidupan dalam keseharian dalam suasana yang alamiah. Tradisi memandang manusia secara aktif menginterpretasikan pengalaman mereka sehingga mereka dapat memahami lingkungannya melalui pengalaman personal dan langsung dengan lingkungannya. Titik berat tradisi fenomenologi adalah pada bagaimana individu berpresepsi serta memberikan interpretasi pada pengalaman subyektifnya.

Lokasi penelitian ini dilaksanakan di Kelurahan Waibalun, Kecamatan Larantuka, Kabupaten Flores Timur-Nusa Tenggara Timur. Teknik pengumpulan data dalam penelitian ini menggunakan observasi, wawancara, dan dokumentasi. Validitas penelitian dengan menggunakan triangulasi sumber dan teknik penelitian. Sedangkan analisis data reduksi data, display data, dan verifikasi/ kesimpulan.

\section{HASIL PENELITIAN}

1. Persepsi masyarakat Lamaholot terhadap konversi Belis GG ke bentuk lain

Kesediaan merubah bentuk Belis GG kebentuk lain merupakan partisipasi 
masyarakat Lamaholot dalam pembangunan berkelanjutan bidang budaya. Dalam pergantian bentuk Belis tentunya mempunyai pro dan kontra dalam perealisasiannya. Untuk itu harus mempunyai alasan-alasan yang membuat masyarakat bersedia melaksanakannya sebagai bentuk apresiasi terhadap konsep pembangunan berkelanjutan. Dari hasil obeservasi, wawancara, dan studi dokumentasi didapatkan bahwa; pandangan atau persepsi masyarakat Lamaholot terhadap konversi Belis GG kebentuk lain adalah untuk melestarikan budaya. Hal ini Sebagai respon terhadap kondisi kelangkaan GG di Flores Timur. Dengan kelangkaan ini maka pelaksanaan upacara adat perkawinan sangat sulit untuk dilaksanakan. Oleh karena itu apabila mempertahankan penggunaan GG sebagai Belis akan mengakibatkan budaya perkawinan tidak dapat dijalankan.

\section{Partisipasi masyarakat Lamaholot} dalam pembangunan berkelanjutan.

Partisipasi yang dilakukan oleh masyarakat Lamaholot yang dimaksudkan disini adalah partisipasi dalam bidang budaya. Hal ini didapat dari hasil observasi, wawancara, dan dokumentasi yang dilakukan dilapangan. Dari hasil wawancara diperoleh adanya keterangan bahwa masyarakat Lamaholot yang menetap dikelurahan Waibalun menggunakan GG dalam upacara adat perkawinan sejumlah 3 batang. Berdasarkan keterangan dilapangan akhir-akhir ini tuntutan jumlah tersebut sudah dapat dikurangi. Hal itu disesuaikan dengan kemampuan pihak laki-laki. Namun jika tuntutan terhadap GG tidak dapat dipenuhi maka pemenuhannya dapat digantikan dengan benda lain. Jenis dan jumlah benda yang dimaksud tergantung pada hasil kesepakatan.

Berdasarkan data lapangan sebagaimana yang telah dibeberkan diatas mengindikasikan bahwa masyarakat Lamaholot menyepakati pergantian GG dengan benda lain dan atau pengurangan jumlah GG sematamata untuk mempertahankan budaya perkawinan yang merupakan tradisi yang didalamnya terkandung nilai-nilai luhur. Respon yang dibarengi dengan tindakan nyata dalam perkawinan adat Lamaholot adalah wujud penyesuaian keterbatsan sumber daya alam dengan kebutuhan kebudayaan dimaksud. 
Dari respon yang telah dilakukan oleh masyarakat Lamaholot ini dapat dikatakan bahwa masyarakat telah berpartisipasi dalam pelestarian budaya. Pengkonversian wujud Belis GG kebentuk lain merupakan bentuk partisipasi masyarakat Lamaholot dalam pelestarian budaya yang mendukung konsep pembangunan berkelanjutan bidang budaya. Hal ini dibuktikan dengan pengurangan GG dalam pemenuhan adat perkawinan. Selain itu apabila pemenuhan Belis GG masih belum dapat dipenuhi maka akan menggunakan benda lain sebagai pengganti wujud GG tersebut.

\section{PEMBAHASAN PENELITIAN}

1. Persepsi masyarakat Lamaholot terhadap konversi wujud Belis GG ke bentuk lain

Persepsi masyarakat Lamaholot terhadap penggunaan GG sebagai Belis telah berubah. Hal ini dibuktikan dengan kesediaan masyarakat Lamaholot menggunakan wujud lain untuk menggantikan GG. Masyarakat Lamaholot melakukan perubahan wujud dimaksud sebagai respon atas kelangkaan GG yang ada di Flores Timur. Bila wujud GG terus dipertahankan maka akan mengakibatkan budaya perkawinan masyarakat Lamaholot tidak dapat terlaksana. Dengan demikian perubahan wujud GG dapat dimaknai sebagai bentuk pelestarian budaya.

Halim, (2005) mengemukakan Persepsi adalah proses dimana seseorang memperoleh informasi dari lingkungan sekitar. Persepsi merupakan suatu hal yang aktif. Persepsi memerlukan pertemuan nyata dengan suatu benda dan juga membutuhkan proses kognisi serta afeksi. Persepsi membantu individu untuk menggambarkan dan menjelaskan apa yang dilakukan oleh individu. Berpersepsi atau mengamati sama dengan percaya pada dunia. Manusia digambarkan berada dalam dunia dan persepsi ialah relasi asli manusia dengan dunia. Hal senada juga diungkapkan oleh Rakhmat (dalam Irawan, 2010) bahwa persepsi merupakan pengalaman mengenai objek, peristiwa, atau hubungan yang diperoleh dengan menyimpulkan informasi dan menafsirkan yang melibatkan sensasi, atensi, ekspetasi, motivasi dan memori.

Persepsi yang telah diberikan oleh masyarakat Lamaholot ini merupakan hasil dari menafsirkan dan menyimpulkan informasi dari lingkungan sekitar yang kemudian dihubungkan dengan tradisi dalam kebudayaan yang mereka jalankan. Hasil dari persepsi ini masyarakat kemudian 
bersedia melakukan perubahan wujud Belis GG kebentuk lain. perubahan bentuk Belis GG kebentuk lain merupakan hasil persepsi masyarakat Lamaholot untuk melestarikan budaya. Hal ini kemudian implikasi terhadap pembangunan berkelanjutan bidang budaya.

Dari persepsi yang diberikan oleh masyarakat Lamaholot ini, membuktikan masyarakat telah berperan dalam perubahan dan pembangunan. Perubahan dan pembangunan yang dilakukan adalah didalam institusi sosial, khususnya pada komunitas masyarakat mereka. Hal ini sejalan dengan perpsektif sosial-budaya yang berkaitan dengan manusia dan interaksi dengan sesamanya. Seperti yang dikemukakan oleh Puslitbang Kemdiknas (2010, hlm.16); "perspektif sosial-budaya merupakan institusi sosial dan peran manusia dalam perubahan dan pembangunan".

Dalam proses pembangunan berkelanjutan yang dilakukan oleh masyarakat Lamaholot tersebut merupakan suatu langkah perubahan untuk mencapai suatu tujuan tertentu. Tujuannya adalah untuk menjalankan kebudayaan yang mereka miliki. Selain untuk menjalankan budaya, perubahan ini dilakukan agar nilainilai yang ada didalam adat perkawinan tidak hilang begitu saja. Dengan adanya proses perubahan ini maka generasi yang akan datang juga dapat merasakan, melihat dan sadar akan nilai-nilai yang terkandung dalam upacara adat perkawinan.

Didalam upacara adat perkawinan khususnya yang berkaitan dengan Belis terkandung nilai-nilai yang sangat luhur. Nilai luhur ini berhubungan dengan sesama manusia maka kiranya layak dipertahankan oleh masyarakat Lamaholot. Walaupun terjadi perubahan bentuk, nilai-nilai yang ada dalam sebuah $G G$ tersebut tidak dihilangkan. Oleh karena itu tindakan yang telah dilakukan oleh masyarakat Lamaholot telah sesuai dengan konsep pembangunan berkelanjutan. Tindakan ini memperlihatkan bahwa masyarakat Lamaholot mampu bersikap bijaksana dalam mengimplementasikan kebudayaan yang sesuai dengan tujuan pembangunan berkelanjutan. Selain menunjukan keterlibatan dan keberpihakan terhadap pembangunan berkelanjutan, konversi GG yang dilakukan oleh masyarakat Lamaholot adalah upaya untuk menunjukan eksistensinya sebagai masyarakat berbudaya. 
2. Konversi Belis GG sebagai upaya melaksanakan pembangunan

berkelanjutan

Pengkonversian wujud Belis GG kebentuk lain merupakan bentuk partisipasi masyarakat Lamaholot dalam pelestarian budaya yang mendukung konsep pembangunan berkelanjutan bidang budaya. Bidang budaya merupakan aspek penting dalam pembangunan. Pembangunan budaya menjadi pertimbangan yang utuh dan menyeluruh dengan pembangunan pada umumnya. Salah satu aspek dalam budaya adalah perkawinan atau yang dapat disebut dengan budaya perkawinan. Dengan demikian maka perkawinan, dalam kaitan dengan budaya kiranya harus mampu dikemas sehingga keberadaannya dapat memenuhi syarat pembangunan secara umum. Partisipasi masyarakat dalam kerangka budaya perkawinan merupakan gerak dalam mendorong pembangunan berkelanjutan.

Partisipasi masyarakat Lamaholot dalam budaya perkawinan adalah bentuk suport sistem dari pembangunan dimaksud. Partisipasi yang demikian adalah partisipasi dalam prespektif sosial-budaya. Dalam rangka menjalankan pembangunan berkelanjutan dalam bidang budaya maka masyarakat Lamaholot menyetujui adanya pergantian GG ke bentuk lain sebagai salah satu media dalam Belis.

Dalam budaya setempat GG menjadi media utama yang digunakan sebagai ikon Belis. Tuntutan budaya perkawinan yang berkaitan dengan GG kini telah mengalami perubahan bentuk. Perubahan bentuk dimaksut berimbas pada tuntutan Belis. Hal ini terlihat dari pengurangan jumlah $\mathrm{GG}$ sebagai Belis dan pergantian GG ke bentuk uang. Pengkonversian ini dilakukan semata-mata untuk tetap menjalankan kebudayaan yang telah diwariskan secara turun temurun. Karena apabila tidak melakukan pengkonversian ini maka budaya perkawinan pada masyarakat Lamaholot perlahan akan hilang dikarenakan semakin sulit untuk dilaksanakan.

Partisipasi adalah suatu tindakan turut serta baik secara individu maupun kelompok dalam suatu kegiatan tertentu. Dalam Kamus Bahasa Indonesia, partisipasi adalah perihal turut berperan serta pada suatu kegiatan atau keikutsertaan atau peran serta. Dengan demikian tindakan yang telah dilakukan oleh masyarakat Lamaholot merupakan sebuah bentuk partisipasi. Hal ini didasari oleh kesediaan 
masyarakat Lamaholot untuk bersedia mengkonversikan Belis GG ke bentuk lain.

Bentuk partisipasi yang dilakukan oleh masyarakat Lamaholot ini merupakan partisipasi yang dilakukan secara bersamasama dengan orang lain, atas dasar kesepakatan, keterlibatan emosi dan tujuan tertentu. Seperti yang dikatakan Henryk1 (2013, hlm.613) “Konsep partisipasi mencakup kerjasama antara semua unsur terkait dan merupakan suatu kesepakatan, harapan, persepsi dan sistem komunikasi dimana kemampuan dan pendidikan mempengaruhi sikap dan cara berprilaku seseorang."

Dengan demikian melihat partisipasi yang telah dilakukan oleh masyarakat Lamaholot, maka masyarakat telah berpikir tentang pembangunan berkelanjutan dalam bidang budaya khususnya dalam adat perkawinan. Seperti yang dikemukakan, oleh I Nyoman Sumaryadi, (2010,hlm. 46) terdapat berbagai cara untuk berpartisipasi dengan mengatakan “...baik dalam bentuk pernyataan maupun dalam bentuk kegiatan dengan memberi masukan pikiran, tenaga, waktu, keahlian, modal dan atau materi, serta ikut memanfaatkan dan menikmati hasil -hasil pembangunan".
Berkaitan dengan PKn, berpatisipasi untuk mencapai tujuan dan cita-cita negara merupakan salah satu perilaku untuk menjadi warga negara yang baik, sesuai dengan tujuan PKn. Seperti yang dikemukakan Wahab dan Saprya (2011), "Pendidikan Kewarganegaraan (civic/citizenship education) bertujuan untuk membentuk warga negara yang baik (to be good citizens)." Untuk menjadi warga negara yang baik tentunya harus mempunyai kriteria-kriteria tertentu. Numan Somantri (dalam Wahab dan Saprya, 2011, hlm. 311) menyatakan: "warga negara yang baik adalah warga negara yang patriotik, toleran, setia terhadap bangsa dan negara, beragama, demokratis ..., Pacasila sejati." Sedangkan kriteria lain dikemukakan oleh Azis Wahab (dalam Wahab dan Saprya, 2011, hlm. 311):

Warga negara yang baik adalah warga negara yang memahami dan mampu melaksanakan dengan baik hak-hak dan kewajibannya sebagai individu warga negara, memiliki kepekaan dan tanggung jawab sosial, mampu memecahkan masalah-masalahnya sendiri dan juga masalah-masalah kemasyarakatan secara cerdas sesuai dengan fungsi dan peranannya (socially sensitive, socially 
responsible, dan socially intetligence), memiliki sikap disiplin pribadi, mampu berpikir kritis kreatif, dan inovatif agar dicapai kualitas pribadi dan perilaku warga negara dan warga masyarakat yang baik (socio civic behavior dan desirable personal qualities).

Dengan demikian maka partisipasi yang telah dilakukan oleh masyarakat Lamaholot telah berjalan sesuai dengan tujuan pendidikan kewarganegaraan.

Tindakan yang telah dilakukan oleh masyarakat Lamaholot membuktikan bahwa masyarakat Lamaholot mampu berpikir secara cerdas dalam berpartisipasi menyelesaikan masalah yang dihadapinya. Hal ini terlihat dari : (1) kemampuan masyarakat berpikir tentang cara melaksanakan upacara adat perkawinan tanpa ketersediaan gading gajah. Ini dibuktikan dengan pengurangan jumlah gading gajah dalam tuntutan adat perkawinan dan pergantian gading gajah kebentuk lain sebagai Belis. kemampuan masyarakat Lamaholot dalam menyesuaikan kebutuhan kebudayaan dengan ketersediaan GG. Hal ini termaknai dengan penggunaan wujud lain dengan tetap menjunjung nilai-nilai yang terkandung dalam GG. Masyarakat
Lamaholot dipandang mampu mengkomunikasikan nilai-nilai budaya yang terkandung dalam GG meskipun GG telah digantikan dengan wujud lain.

Partisipasi masyarakat Lamaholot yang telah mengkonversikan Belis GG kewujud lain ini dapat dijadikan bahan pembelajaran bagi daerah-daerah lain yang mempunyai permasalahan yang sama dalam menjalankan tradisi atau adat istiadatnya. Karena mengingat PKn mencakup suatu pengalaman belajar baik itu disekolah maupun di luar sekolah atau di masyarakat seperti yang terjadi di lingkungan keluarga, dalam organisasi keagamaan, dalam organisasi kemasyarakatan dan dalam media. Cogan (dalam Budimansyah dan Suryadi, 2008)

Dengan demikian masyarakat Lamaholot sebenarnya telah menunjukan kompetensi-kompetensi yang menjadi tujuan dari PKn. Oleh karena itu maka ide dan tindakan yang dilakukan oleh masyarakat Lamaholot adalah sebuah pembelajaran yang dapat dikembangkan melalui pembelajaran PKn disekolah. Fenomena dalam masyarakat Lamaholot dapat dijadikan contoh dalam pembelajaran PKn khususnya yang berkaitan dengan partisipasi masyarakat dalam pembangunan berkelanjutan bidang kebudayaan. 


\section{KESIMPULAN}

Partisipasi yang dilakukan oleh masyarakat Lamaholot adalah partisipasi dalam pelestarian budaya. Partisipasi ini dilakukan dengan bersedia mengurangi jumlah GG, maupun mengkonveriskan GG sebagai Belis kedalam wujud lain. Wujud lain yang dipilih sebagai pengganti adalah wajaklolon yang berisikan sejumlah uang sesuai kesepakatan dalam musyawarah adat. Pengurangan jumlah Belis maupun pergantian GG sebagai wujud Belis merupakan cara yang dilakukan untuk melestarikan budaya perkawinan masyarakat Lamaholot.

Kesediaan ini menunjukan bahwa masyarakat Lamaholot telah berpartisipasi langsung dalam pembangunan berkelanjutan khususnya perspektif sosial budaya pada bidang kebudayaan. Dengan bersedia mengurangi jumlah GG, maupun mengkonversikan GG sebagai Belis kedalam wujud lain maka budaya masyarakat Lamaholot dalam adat perkawinan dapat tetap dilaksanakan. Karena apabila tidak melakukan pengurangan dan pengkonversian GG ini maka budaya perkawinan pada masyarakat Lamaholot perlahan akan hilang karena pemenuhan tuntutan Belis semakin sulit untuk dilaksanakan.
Proses perubahan ini menunjukan kesadaran dari masyarakat Lamaholot dalam melestarikan budaya. Bahwa pelestarian budaya bukan semata-mata mempertahankan bentuk budaya yang ada, tetapi dengan mempertahankan nilai yang ada didalam budaya tersebut. Proses pembinaan kesadaran tersebut salah satunya melalui proses internalisasi nilai pendidikan tradisi yang secara terus menerus dilakukan oleh masyarakat Lamaholot. Karena masyarakat Lamaholot merasa bahwa nilai-nilai yang ada dalam sebuah Belis itu sangat penting.

Berkaitan dengan PKn, proses melestarikan kebudayaan merupakan salah satu tujuan dari PKn, terutama PKn kemasyarakatan. Karena mengingat PKn tidak hanya terfokus dalam domain formal di persekolahan, karena warga negara lebih banyak menggunakan waktu nya dalam lingkungan masyarakat. Sehingga tindakan yang telah dilakukan oleh masyarakat Lamaholot ini memberikan kontribusi yang sangat baik terhadap PKn kemasyarakatan, guna membentuk partisipasi dan kesadaran warga negara dalam melestarikan kebudayaan.

Hasil Penelitian ini menggambarkan tujuan dari PKn. Meskipun masyarakat Lamaholot tidak terlalu mengerti dan 
memahami komepetensi-kompetensi kewarganegaraan, namun dalam aplikasi dilapangan ternyata masyarakat Lamaholot telah melakukan pengamalan nilai-nilai kompetensi kewarganegaraan dalam kesehariannya. Sesuai dengan tujuan dari Pendidikan Kewarganegaraan itu sendiri, yakni meningkatkatkan partisipasi warga negara. Dengan melestarikan budaya perkawinan, maka masyarakat Lamaholot telah mencerminkan perilaku sebagai warga negara yang baik sesuai dengan tujuan dari PKn. Seperti berpartisipasi aktif dalam kehidupan terutama dalam hal dalam melestarikan kebudayaan khususnya budaya perkawinan.

\section{DAFTAR PUSTAKA}

Alwasilah, A.C. (2009). Pokoknya Kualitatif (Dasar-Dasar Merancang dan Melakukan Penelitian Kualitatif). Jakarta: Pustaka Jaya.

Arikunto, Suharsimi. (2006). Prosedur Penelitian Suatu Pendekatan Praktik. Jakarta: Rineka Cipta.

Budimansyah, Dasim. Dan Suryadi, Karim (2008). PKN dan Masyarakat Multikultural. Bandung: Program Studi Pendidikan Kewarganegaraan.
Bungin, B. (2007). Penelitian Kualitatif. Jakarta: Kencana Prenada Media Group.

Bungin, B. (2012). Penelitian Kualitatif: Edisi Kedua. Jakarta: Kencana Prenada Media Group.

Dwiningrum,S.I.A, (2011). Desentralisasi dan Partisipasi Masyarakat dalam Pendidikan. Yogyakarta: Pustaka Pelajar.

Halim, Deddy. (2005), Psikologi Arsitektur: Pengantar Kajian Lintas Disiplin, Grasindo, Jakarta

Isbandi Rukminto Adi. (2007). Perencanaan Partisipatoris Berbasis Aset Komunitas: dari Pemikiran Menuju Penerapan, Depok: FISIP IU Press.

Koentjaraningrat, (2009). Pengantar Ilmu Antropologi (Edisi Revisi 2009). Jakarta: Rineka Cipta.

Kuswarno, Engkus. (2008). Etnografi Komunikasi: Pengantar dan Contoh Penelitiannya.Bandung: Widya Padjajaran

Moleong, L.J. (2003). Metode Penelitian Kualitatif. Bandung: PT Remaja Rosdakarya Bandung. 
Moleong, J.L. (2004). Metode Penelitian Kualitatif. Bandung: PT Remaja Rosdakarya Bandung

Moleong, J.L. (2007). Metode Penelitian Kualitatif. Bandung: PT Remaja Rosdakarya Bandung

Muktar, (2013). Metode Praktis Penelitian Deskriptif Kualitatif. Jakarta: REFERENSI (GP Press Group)

Mulyana, Deddy (2001), Ilmu Komunikasi Suatu Pengantar. Bandung : PT. Remaja Rosda Karya

Mulyana, Deddy. (2008). Metodologi Penelitian Komunikasi. Bandung : Remaja Rosda Karya.

Pemerintah Provinsi Sumatera Selatan. (2001). Palembang: Pemprov

Sapriya dan Winataputra, Udin. (2004). Pendidikan Kewarganegaraan: Model Pengembangan Materi dan Pembelajaran. Bandung: Laboratorium PKn-FPIPS UPI.

Satori, Djam'an dan Komariah, Aan (2009). Metodologi Penelitian Kualitatif. Bandung : Alfabeta
Sobur, Alex. (2013).Filsafat Komunikasi

Tradisi dan Metode Fenomenologi.

Bandung: PT. Remaja Rosda

Karya.

Soekanto, Soerjono.(1994) Sosiologi Suatu Pengantar, Jakarta: PT Raja Grafindo Persada.

Soekanto, Soejono. (2004). Sosiologi Suatu Pengantar. Jakarta: PT Raja Grafindo Persada.

Sugiyono. (2011). Metode Penelitian

Pendidikan (Pendekatan

Kuantitatif, Kualitatif dan $R \& D$ ).

Bandung: Alfabeta.

Sugiyono. (2013). Memahami Penelitian Kualitatif . Bandung: Alfabeta.

Sukidin. (2002). Metode Penelitian Kualitatif Perspektif Mikro. Surabaya: Insan Cendekia

Sulasman dan Setia Gumilar. (2013). TeoriTeori Kebudayaan Dari Teori Hingga Aplikasi. Bandung: Pustaka Setia.

Sulaeman, Munandar. (2012). Ilmu Budaya Dasar, Pengantar Ke Ilmu Sosial Budaya Dasar/ISBD/ Social Culture. Bandung: PT Refika Adikarya 
Suprastowo, Philip dkk. (2010). Model Pendidikan untuk Pembangunan Berkelanjutan (Education for Sustainable Development/ESD) melalui Kegiatan Intrakurikuler. Jakarta: Pusat Penelitian Kebijakan Badan Penelitian dan Pengembangan Kementerian Pendidikan Nasional

Syahri, Mohamad. (2013). Pembangunan Berkelanjutan Berbasis Green Moral. Bandung: Widya Aksara Press

Syani, Abdul. (1994). Sosiologi dan Perubahan Masyarakat. Bandar Lampung: Pustaka Jaya.

Tutik, Triwulan Titik. (2010). Hukum Perdata dalam Sistem Hukum Nasional. Jakarta: Kencana Prenada Media Group.

Wahab, Abdul Aziz dan Sapriya (2011). Teori dan Landasan Pendidikan Kewarganegaraan. Bandung : Alfabeta

Winarno, (2012). Paradigma Baru Pendidikan. Kewarganegaraan (Panduan Kuliah di Perguruan Tinggi), Jakarta: Bumi Aksara.
Winataputra, Udin Saripudin. (2012). Pendidikan Kewarganegaraan Dalam Perspektif Pendidikan Untuk Mencerdaskan Kehidupan Bangsa (Gagasan, Instrumen, dan Praksis). Bandung: Widya Aksara Press

\section{Jurnal :}

Anderson, A. (2014). Climate Change Education for Mitigation and Adaptation . Journal of Education for Sustainable Development, 6 (2), hlm. 191206

An-Naf.J.(2005). Pembangunan Berkelanjutan Dan Relevansinya Untuk Indonesia. Jurnal FISIP: MADANI , 2 (2).

Deviyanti, Dea. (2013) Studi Tentang Partisipasi Masyarakat Dalam Pembangunan Di Kelurahan Karang Jati Kecamatan Balikpapan Tengah. eJournal Administrasi Negara, (1) 2, hlm. 380-394

Henryk1, S.(2013). Partisipasi Masyarakat Dalam Pembangunan Di Kelurahan Sungai Keledang Kecamatan Samarinda Seberang Kota Samarinda. eJournal Ilmu 
Pemerintahan, 1 (2), hlm 612 625

Hopkins, C (2012). Twenty Years of Education for Sustainable Development. Journal of Education for Sustainable Development, 6 (1), hlm.1-4

Murdiono, M (2010). Strategi Internalisasi Nilai-Nilai Moral Religius Dalam Proses Pembelajaran di Perguruan Tinggi. Jurnal Ilmiah Pendidikan Cakrawala Pendidikan, 1 (3)

Nurhayati.E.D. (2013). Perubahan Sistem Perkawinan Masyarakat Besemah Di Pagar Alam Provinsi Sumatera Selatan. Jurnal Skripsi Jurusan Sosiologi Fakultas Ilmu Sosial Dan Ilmu Politik Universitas Sriwijaya

Pujiwiyana. (2010). Perubahan Perilaku Masyarakat Ditinjau Dari Sudut Budaya. Jurnal Seni Dan Budaya, 1 (1), hlm 23-34

Rosana, E. (2011). Modernisasi Dan Perubahan Sosial. Jurnal TAPIs , 7 (12), hlm. 31-47
Suryaningsih, H.W dkk (2012). Persepsi Dan Perilaku Masyarakat Dalam Upaya Pelestarian Hutan Rakyat Di Desa Karangrejo Kecamatan Loano Kabupaten Purworejo. Jurnal EKOSAINS 4 (3), hlm. 27 38

Utama,I.M.A. (2008) Pembangunan Berkelanjutan Dalam Kerangka Otonomi Daerah. Jurnal Konstitusi PKK-FH Universitas Udayana, 1 (1), hlm. 9.

Qian, Wei. (2013). Embracing the Paradox in Educational Change for Sustainable Development: A Case of Accounting . Journal of Education for Sustainable Development, 7 (1), hlm. 75-93

\section{Sumber Internet :}

Jaya, A. (2004). 'Konsep Pembangunan Berkelanjutan' [Online].

Tersedia di: http://file.upi.edu/Direktori/FIP/J UR._PEND._LUAR_SEKOLA H/195207251978031ACE_SURYADI/askar_jaya.pdf . Diakses 26 November 2014. 
Nasution,A.Z. (2013) 'Prinsip-Prinsip

Pembangunan Berkelanjutan

atau Principle of Sustainability

Development' [Online]. Tersedia

di: http://www.bangazul.com/-

prinsip-prinsip-pembangunan-

berkelanjutan. Diakses 26

November 2014.

Salim, Emil (2003) 'Sains Dan

Pembangunan Berkelanjutan'

[Online]. Tersedia di:

ttp://www.cornerstone-

msc.net/peat-

portal/view_file.cfm?fileid=439.

Diakses 25 Februari 2014. 